\title{
Towards a Politics of Collective Empowerment: Learning from Hill Women in Rural Uttarakhand, India
}

\author{
Divya Sharma and Ratna M. Sudarshan'
}

\begin{abstract}
This article argues that to understand the conditions that enable effective participation by women in politics, analysis is needed not just of the characteristics and performance of elected women leaders but also the extent to which village communities are engaged through collective processes, in demanding accountability from those elected. The article presents the experiences of a women's movement in the Uttarakhand that has evolved from a programme of environmental education in the region. Over the years, this movement has developed a strong political consciousness. Women's participation in Whole Village Groups has paved the way for active engagement with local governance institutions. The article concludes that by enabling collective spaces, reinforcing norms of equality and inclusiveness through debate and negotiation, building networks across villages and supporting each other through conflicts and confrontation, the organisations concerned have demonstrated that processes of collective empowerment can lead to effective political participation.
\end{abstract}

\begin{abstract}
1 Background
The Women's Reservation Bill, passed in the Lower House of the Indian Parliament in March 2010, seeks to reserve 33 per cent of seats in Parliament for women. Earlier Constitutional Amendments (73rd and 74th) passed in 1993 reserved 33 per cent of seats in the Panchayati Raj Institutions (local governance institutions) (PRIs) ${ }^{1}$ for women; some states have increased the reservation to 50 per cent and a further amendment to implement this nationwide, is under consideration. Gurrently, debate continues on whether reservation of seats in Parliament will prove to be effective in enhancing women's political voice; and whether quotas are needed within the quota, minority group wise and/or caste wise.
\end{abstract}

The Constitution provides reservations to grant women political representation - at present in local governance institutions - and the Union and State Governments are bound to see that the constitutional mandate is respected. It appears though that the actual extent to which, and the pace at which, these provisions are implemented is mediated by 'considerations of political equations and sensitivities' (Academics for Panchayati Raj 2009). Fiscal decentralisation and planning autonomy for PRIs are both limited. In addition, elected women representatives (EWRs) have to function within a persisting patriarchal framework of society. The Indian Constitution seeks to lead change in an explicit direction that is often at odds with the pervading social realities; it is expected of the government that it would mediate and control any tensions that arise between the two. The PRI reservations for women are one example of a decision taken 'at the top'. As a result, women elected to PRI positions may or may not have any prior experience of being in the public space.

The experience with women in PRIs has varied widely. It is now 17 years since the enactment of the amendment and considerable experience is available about the effectiveness or implications of such participation. In an attempt to pull together this experience, the Ministry of Panchayati Raj, Government of India, commissioned a nationwide survey of EWRs, which provides us for the first time with an overall picture of the profile, political

IDS Bulletin Volume 41 Number 5 September 2010 (c) 2010 The Authors. Journal compilation (C) Institute of Development Studies Published by Blackwell Publishing Ltd, 9600 Garsington Road, Oxford OX4 2DQ, UK and 350 Main Street, Malden, MA 02148, USA 
career and quality of participation of EWRs (Government of India 2008). The survey finds that roughly 20 per cent of EWRs and slightly under this percentage of elected male representatives (EMR) report that other members of the family had previously contested panchayat (elected Village Council) elections. Of that 20 per cent, 60 per cent of women and 36 per cent of men said that their spouse had contested panchayat elections. This data does confirm that many of the EWRs who are in the panchayats come from families that have been participating in these institutions. To explore this further, the motivation to contest in the elections was investigated. Some 30 per cent of EWRs (but only 1 per cent of EMRs) said their spouse had motivated them to contest their first election. With both men and women, around 22 per cent were motivated by community groups; 7 per cent of women (and 10 per cent of men) were motivated by a political party. Social problems motivated 36 per cent of EWRs and 60 per cent of EMRs to nominate themselves in the elections. Around 37 per cent of the EWRs were motivated to participate because of the system of reserved seats for women.

Training and capacity building programmes are conducted for EWRs both by government and non-government organisations. ${ }^{2}$ The reasoning behind these is that even if EWRs have no prior experience with politics, appropriate training can fill this potential gap in their knowledge and orientation. The survey showed that after being elected, just over half ( 54 per cent EWR; 65 per cent EMR) received training/orientation. Of those who wished for further training (around 60 per cent), 82 per cent said the training was too short and 14-17 per cent said it was not easy to understand the content of the training. More EWRs than EMRs ( 7 per cent and 2 per cent) said training would be more helpful if it was in the local language.

Most EWRs do not abandon their traditional gender roles once elected. The report finds however that around 30 per cent of EWRs said they had reduced the time they spent on household responsibilities after being elected; and 60 per cent of these said that other family members spent more time on these responsibilities.

In some villages in Himachal Pradesh, a women's gram sabha (village assembly consisting of all persons on the village electoral rolls) is held prior to the main gram sabha to enable women to formulate their agenda more forcefully (Government of India 2008: 80) Overall, however, the report concludes that 'reservations may facilitate a critical breakthrough in the political career of elected representatives, but it does not have much impact on performance as political functionaries' (Government of India 2008: 152). Through field studies in hill states in India, and especially in Uttarakhand, ${ }^{3}$ the Institute of Social Studies Trust (ISST) has explored the question of what in practice seems to make a difference to governance and political participation of women once in office. In states where traditional male dominated bodies have a strong hold, it is far more difficult for women to play an effective role. However, Uttarakhand is an example of a setting where sustained mobilisation of women into village level groups around issues of immediate practical concern, has led to federations at a regional level. While women's initial concerns were around immediate and practical needs, there has been a gradual and organic expansion of their activities to issues of public accountability and political participation.

\section{Observations from the field}

Previous research on women's political participation at the panchayat level, particularly focusing on reservation has mapped out the performance of women leaders, their impact on governance, and supporting a gender equity agenda (Chattopadhyay and Duflo 2003; Ban and Rao 2006). A study carried out by the Institute of Social Studies Trust (ISST) (Bisht and Sudarshan 2005) tried to explain the conditions under which effective women's leadership emerges within existing structures of governance. The study sought to understand what allows women to exercise transformational, not just transactional, leadership. Such leadership would go beyond representation, and be reflected in women being able to bring new issues to the political and development agenda, reflecting the specificity of women's experience; and enabling them to influence allocations according to their priorities. The analysis of experiences of a women's movement in rural Uttarakhand, given below, suggests that an exclusive focus on elected women and their leadership is inadequate to understand the emergence of women's political voice. The framework for looking at political participation and governance needs to be broadened to include 
the ways in which democratic and collective processes at the village level can be strengthened, including interaction and engagement with state machinery to generate accountability. ${ }^{4}$

Findings of the ISST study (Bisht and Sudarshan 2005) showed that in Uttaranchal ${ }^{5}$ and Himachal, women were well represented in the panchayat institutions as a result of reservations. However, these EWRs could not take up gender concerns or even issues relating to village needs, partly because the system itself was inflexible, and little delegation of powers had taken place for PRIs. The study concluded that the voices of women would emerge as they reflect and articulate views in spaces in which they feel secure. Women's groups have played an extremely important role in creating and nurturing such spaces.

Reservation in panchayats is not a substitute in any way for the role of these groups. Resources need to continue to flow to supporting women's groups and activities outside of the formal structures and its supporting institutions and activities (Bisht and Sudarshan 2005).

\subsection{Experiences of the Uttarakhand Women's Federation}

This tentative conclusion can be reaffirmed more strongly, based on the experiences of the Uttarakhand Mahila Parishad - UMP

(Uttarakhand Women's Federation) up until the present (Sharma 2010). Political participation of women in this instance has emerged in the context of a women's movement in the hill villages. The UMP is a network of around 450 women's groups (Whole Village Groups or WVGs), spread over villages in seven districts of Uttarakhand. The women's groups are a part of the larger network under the umbrella of Uttarakhand Seva Nidhi Paryavaran Shikshan Sansthan (Uttarakhand Environment Education Centre, USNPSS), based in Almora, which has been working in the hill villages of Uttarakhand since 1987 in partnership with community-based organisations (CBOs) in different regions. The founding philosophy of USNPSS drew on an understanding of the link between environmental degradation and livelihood sustainability. Groups at the village level each have their own unique trajectories of development determined by the specific social, economic and political context of the village.

Over the last two decades, larger socioeconomic changes have occurred in the villages and the
WVGs have played a role in moulding some of these changes. The broad trajectory that has emerged through accounts from several villages indicates that the agenda of the women's groups was occupied by issues of maintenance and running of the balwadi (pre-primary centres started by USNPSS for children 2-6 years old), children's education, natural resource management in the initial years, and then gradually expanded to include active engagement with state institutions, demanding accountability and active participation in formal governance institutions - in gram sabha and panchayat activities.

A critical organisational principle has been to include all women in the village in the group, irrespective of their caste, or economic status. This is partly possible because hill villages in Uttarakhand are small with a relatively lower level of socioeconomic differentiation. Estimates for the state as a whole suggest that the vast majority of households are Hindu and that 62 per cent of Uttarakhand's households do not belong to scheduled castes, scheduled tribes or other backward classes (Government of India 2009). Further, the functioning of the groups at the village level demonstrates that an active community of women was not a given, but has evolved over the years through interventions, predominantly creation of spaces for discussion and negotiation which recognise the differences and conflicts in the village community rather than trying to supersede them. At regional meetings and state meetings of the groups, women have to live together and eat together with women of other castes. A USNPSS worker says that some women are still reluctant to eat with everyone. Changes in attitude are achieved only through a long-drawn and often conflictual process.

Strategies used to encourage inclusiveness include group rituals, such as performing folk songs and hymns on auspicious occasions in any household in the village or all the women going to every household on the occasion of a festival. One WVG president pointed out that before the formation of the groups, it was unheard of for women to attend wedding ceremonies. As she put it, 'Singing and dancing by women has now become an integral part of the weddings. We also go from house to house on Holi (a spring festival) whereas earlier women did not come out of the houses on Holi. As a result there is also more 
intermixing between people of the scheduled castes and the upper castes'. In another village, several generations of families belonging to each of the two main communities had not spoken to each other for almost 50 years due to an age-old dispute. At initial meetings, the women did not even drink water from each other's houses. Four years later they had started eating at each other's houses. And recently, last year the men also sat together in the village at a wedding and ate together. In the process of working as a collective, women in some instances have thus been able to overcome deep seated prejudices, given sustained reinforcement of group identities over a period of time.

Several WVGs trace their origins to the opening of the balwadi in the village. Women started meeting and discussing issues related to education for their children and then subsequently they became involved in the everyday functioning, monitoring and maintenance of these centres. This process laid the foundation for organising and getting together, engaging in dialogue and taking decisions. Through management of forests, water sources and regulating cattle grazing, women have attempted to address their primary practical concerns for reducing their own burden and also lessening conflict by instituting mechanisms for equal access and distribution of resources. Meetings of the WVGs have become forums for discussion around sustainable use of natural resources. This process required addressing power relations within the village. The fact that women from all households are a part of the group (although their levels of participation may not be the same) is instrumental in ensuring that women from richer households or higher castes do not set or dominate the agenda. This does mean rendering the groups susceptible to a conflicting time-consuming process of negotiation but it allows for genuine accountability and management of collective resources. Taking decisions such as which household gets allocated the limited amount of money available for construction of toilets or coming to a consensus on equal distribution of water, were key to an organic progression towards actively participating in formal governance institutions.

\subsection{Political participation and reshaping governance}

In recent years, there has been a movement towards active participation in formal governance and the electoral political process. Several women from the WVGs have contested for, and won, the positions of gram pradhan, ward members, and block development committee members, particularly in the panchayat elections in 2008. Significantly, the women themselves decided to field a candidate for state assembly elections in 2006 and this acted as a catalyst for active engagement of women with formal structures of governance and familiarisation with the electoral process. In several villages, the WVG interacts with the panchayat and the district and block level functionaries to put forward their demands and grievances and women are constantly encouraged to attend the open gram sabha meetings.

The role of the WVGs in creating an environment conducive for participation in the electoral process and nurturing leadership among women, is evident. Women have, over the years, acquired the confidence and also the aspiration to affect change through politics and to influence the development agenda. The monthly meetings of the groups have created a space for collectively identifying needs, planning activities, allocating tasks such as cleaning pathways, common village spaces, plantation activity and resolving conflicts that arise within the village (for instance on trespassing cattle, distribution of water, etc.) Over the years, groups have evolved ways of working together, negotiating as a group, with facilitators from community-based organisations and USNPSS emphasising inclusiveness. The authority of the WVGs has been - even if reluctantly - accepted in the villages, reflected in the fact that in many instances, men comply and pay the fines imposed on them for abusive behaviour associated with alcohol consumption.

WVGs in villages across the state have demanded accountability and effective services from government apparatus and functionaries, particularly in the area of education and functioning of primary schools. They have talked to government functionaries, pressurised them as a collective and in certain cases, they have used openly confrontational and public forms of protest such as blocking traffic, street marches and campaigns outside local state institutions. Some instances include ensuring the presence of state managed child development centres - Anganwadis ${ }^{6}$ (the opening of which led to the closure of the community managed balwadis), which provide an equal quality of childcare and, raising voice in 
cases of malfunctioning schools, absent or nonperforming teachers and monitoring attendance registers every month in schools to check irregularities.

In many instances, the engagement of the groups is also going beyond asking state institutions for effective services as recipients. Women are making attempts to influence the development agenda according to their needs and priorities, and succeeding to some extent. This involves challenging existing programmes or other initiatives or modifying them according to local context, e.g. rejecting road construction because it adversely affects the productivity of farms and cuts through water sources, determining where it is built or ensuring that water supply is distributed equally, instead of being directed at households of a particular caste residing in a certain part of the village.

Women in most instances have a sense of being part of a state-wide or at least regional network and not just members of an isolated village level group. At the regional level, the WVGs have held demonstrations and challenged the administration on controversial issues which have wider political implications and do not always have a direct impact on their personal lives or that of their own village. In Chamoli district, for instance, groups along with the local $\mathrm{CBO}$, held demonstrations for adequate compensation for villages where families were displaced for a hydro-electric project.

The regional federation of the UMP in Dwarahat region decided to field a candidate for the State Assembly elections in 2006. The fielding of a candidate to contest mainstream political parties was significant in itself, and the campaign was more significant because the women felt no compulsion to canvass for votes in the same way that political parties did (the making of extravagant promises, holding out of rewards, or active bribery). The federation nominated a woman from a family living below the poverty line and the resources for the campaign were generated through contributions from groups across the state. Practices such as bribing voters with alcohol and money, which is commonplace, were criticised during the campaign. The 'Basket' was chosen as the electoral symbol by the women because it represented their everyday lives: 'It is used every day at home in the kitchen to put in chapattis, to collect the waste from cowsheds, to carry manure to the fields and bring back vegetables: Even babies sleep comfortably in a basket' (Sara and Pande 2008).

The UMP candidate for the State Assembly elections says:

Even though I lost, we all learnt so much during the process of campaigning as well as elections about how nomination takes place, who are the agents, how the electronic voting machines work, the sealing and counting process etc. The Block pramukh (head official) who was from one of the main political parties was trying to influence the voters. All the women blocked the booth and said voting will not start till everyone is cleared from near the voting machines. No one should be allowed to come near the machine.

She further adds,

Before the Lok Sabha Elections (Parliamentary Elections) in 2009 all the big political parties asked me to come and attend their meetings and asked for the UMP's support but I told them that I will go back and discuss it with all the women since it's a collective decision.

The WVGs act as a pressure group demanding accountability from their elected representatives. The activities of the panchayat are in many instances discussed at the group's village meetings, particularly where WVG members are elected representatives. The issue of symbolic representation as opposed to real participation comes up frequently in the context of women's political participation, particularly in the debate on the reservation system. A few women pradhans (elected head of the Village Council) said that they resort to taking help from their husbands but make a distinction between help and yielding complete control. Experiences narrated by women also indicate a learning curve over a period of time where symbolic representation transforms into genuine participation through a gradual process. Women are also cognisant of the need for shifting the agenda of the panchayats from mere construction activity to issues more relevant to their lives. To some extent, active groups have been able to leverage funds through the panchayat for activities that they perceive to be of utmost need in the village or influence the direction of schemes according to their needs. 
The level of participation of women in panchayats differs from village to village and regionally - in the case of some WVGs in some villages, such participation is absent. Reasons cited for not attending gram sabha meetings range from lack of awareness, meetings held at a distance from the village, household responsibilities, and an attitude of 'it is sufficient for the men of the house to go'. Some women say they feel illequipped to contribute because they are not educated. Even in villages where women hitherto have not attended gram sabha meetings, it is increasingly coming up for discussion because of UMP's activities in other areas. Women have to contend with entrenched ways of electoral politics that have become endemic to the system, such as rampant corruption. However, through examples of other women, support provided by $\mathrm{CBO}$ and USNPSS through trainings, and also through experience, they are familiarising themselves with this process and strategies and subsequently challenging them as well.

Women collectively working towards ensuring better quality of education or organising to manage natural resources is often acceptable and garners support from men and the village community, as the 'other' in the former case is the state and its representatives, and in the case of the latter, men have no role or immediate stake in the absence of any direct responsibility. However, there is resistance and even strong protest on other fronts where there is direct conflict of interest or women's actions threaten entrenched social norms. For instance, women protesting against alcohol abuse or challenging domestic violence have elicited strong reactions. Their active participation in electoral politics, acquiring positions of power and in other political bodies has been condemned and has created conflict. This turmoil is reflected in actions, e.g. men not voting for a woman candidate from their village on the grounds that she is the 'daughter of the village', or rumours that the scarcity of rainfall in the region was because 'women have started attending gram sabha meetings and becoming pradhans'.

Women have to negotiate tremendous pressure in this staunchly male dominated bastion of politics but the support of a strong collective force such as the UMP (Uttarakhand Women's Federation) is tilting the scales in their favour. However, the work of the UMP faces impediments on many fronts, as it challenges traditional power structures. The UMP candidate who contested the assembly elections says:

Working as a political activist in the village is not easy. One needs a lot of intelligence to be able to reply to tough questions often asked by men to test your wits.

It is difficult to channelize votes towards WVG members in villages because men who are not happy with the WVG take this opportunity to work against us. How can we win the elections because we have always been against the system? Many times we have made complaints against irregularities in the education department and in the health department, now these people join to oppose our actions and not give us votes. Also, the local functionaries in the block headquarters seem to be threatened by our growing power... so they do not want us to be members of panchayats... we will question their motivation and nobody likes that.

(USNPSS Annual Report 2008: 16)

Empowerment that has happened here has to be understood as a process, not a state of being, and a collective process that is constantly evolving. It is distinct from the measurement of achievement in areas such as levels of literacy, participation in political governance institutions, ownership or control of economic assets.

The WVGs are communities constantly in the 'becoming'. Change has not been linear but went back and forth as women engaged in a process of learning through experiences of their own, as well as of other women as a part of the network. Conflict and breaks in the life histories of groups happen for reasons that include lack of a suitable person willing to take leadership responsibilities; creation of factions in the village during elections for the panchayat and subsequently in the groups; and dispute over mismanagement of the savings fund.

Women's role in defining the parameters of change and its pace is significant but it has come about over a period of time. Women's political participation for instance in this case is clearly in continuum with their social experiences of collectivising, which has helped them to acquire self-confidence, skills, capacity, as well as 
aspiration for change. The WVGs have provided an empowering context for promoting the participation of women in formal governance structures. This has happened indirectly through confidence building and other skills that women have acquired over the years as members of collectives and also through more direct interventions in recent years where women have realised the need to become a part of the governance structure in order to influence the development agenda in their favour, both as members of the village community and as women.

\section{Policy implications}

It is hard to avoid the conclusion that only limited 'fast forwarding' is possible, as women need the space and time to evolve their path and agenda. There have been numerous pathways described in the experiences of the women and variations in the outcomes. Change itself has been possible because the direction of change has not been forced. In an extremely perceptive statement, the Chief Economic Advisor to the Government pointed out that 'For effective policy, what is needed is to take people the way they are and then craft incentive-compatible interventions' (Government of India 2010: 25). Women in remote rural areas in Uttarakhand found 'incentive-compatible interventions' were required to respond to immediate and local specific issues and to enable a self-generated path and pace of change.

Village women do not find it easy to go against 'tradition' or 'customary practices'. Changes in practices are all the more significant because they happen after a process of debate and reflection. Narratives of women across villages indicate that they value their ability to speak publicly at meetings and with state officials, which has come about due to their experiences of speaking at village level meetings. The act of using public spaces in the village by women for their meetings is a stepping stone towards claiming their identity as a group and as women. Women through creating rituals and practices such as performance of songs at weddings and celebrating festivals in public spaces as a group have become active in the public domain and this has become naturalised over the years. Such changes were possible only through collective action. The USNPSS network enabled social and collective spaces with the consequence that challenging gender norms did not result in alienating them which often comes when there are attempts to cause sudden ruptures in everyday normative practices.

Another finding from the study is that if women are able to bring forth their concerns, there is likely to be a degree of conflict. Conflict occurs often within groups, as well as within the larger village community and discussion and dialogue may or not may not result in a consensus but the community undertakes a process of negotiation. The question that should be asked is not only the extent to which people are empowered but for what. Through the course of their work, women are challenging conventional wisdom and practices of the state and in some instances reasserting their own knowledge and practices. For example, choosing oak and other broad-leafed plant species over pine which is being promoted by the forest department; prioritising farms and water sources over road construction; contesting elections but rejecting established malpractices of bribery and alcohol distribution. The movement from addressing practical to strategic gender needs over the years has occurred, but in women's own accounts, the agenda of achieving gender equity is enmeshed with women's attempts to achieve better quality of life. While they value their personal transformations, the ability to be able to speak in public with confidence and deal with 'authority figures' is perceived by women to be significant because it enables them to achieve their developmental priorities. Women have been struggling and raising their voices individually and as a group for proper functioning of hospitals and schools, getting basic amenities like water and electricity in their villages. A CBO worker says, 'These days any government official who comes to the village asks for the president of the WVG, not the gram pradhan because they know that these women will create trouble later if they are not consulted'.

As long as women's groups are concerned with enhancing family income or improving the appearance and cleanliness of the village, their actions are non-conflicting. Once they enter the realm of politics and participation, and begin to question earlier forms of control or demand a reordering of priorities, conflict surfaces. If we are to uphold the spirit and letter of the Constitution, it is imperative to recognise that change and conflict of this kind requires that 
agencies of the government be able to accept and respond to critique and questioning by emerging democratic groups.

The WVG process is intrinsically political, involving negotiation as women identify their needs which may be divergent at times, and devise strategies through a collective process. As a consequence, there is no compartmentalisation of different spheres of life. The deliberative spaces created by WVGs draw upon and are in continuum with, and yet distinct from, everyday spaces of sociality.

Some research studies have argued that women heads of panchayats have an impact on shifting the governance agenda and bringing forth women's needs, while others have articulated that the presence of women representatives does not count for much, as they are mere tokens, and real control rests with male members of the family who represent powerful families. Ban and Rao (2006) argue that while women leaders are not mere tokens because they are likely to be from wealthier families, more knowledgeable about political activities and politically experienced, women leaders perform no differently than male leaders and are no more likely to make decisions that favour women's concerns. The experiences of the UMP, however, emphasise the need to look at processes of governance as well as gender equity in a relational framework, examining the backward and forward linkages and interactions within communities as a dynamic whole. While at one end, engaging in activities as a group, helped certain women to acquire skills and confidence to emerge as leaders and become a part of panchayats, at the other end the WVGs as groups are attempting to interact with panchayats and state institutions to ensure accountability.

Further, if we examine backward and forward linkages at another level, the women's groups in different villages are in constant interaction with each other. Regional federations (comprising WVGs in a region working under a particular $\mathrm{CBO})$ have periodic meetings and representatives from different regions across the state also meet once a year. This sense of connectivity and the fact that women through the WVGs are a part of the organisational network along with the CBOs and USNPSS and not simply on the receiving end of interventions, has generated an identity for rural women at the state level. Women have therefore developed the capacity to develop and introduce their own agenda outside the village at a wider level, and the decision to field a candidate in the state assembly elections, for instance, did not emerge from the USNPSS but the women themselves. The experience of the UMP also shows that women's political aspirations and horizons expand over time through a process of 'doing'. Although unsuccessful in terms of the electoral outcome, the experience of putting up a large election campaign generated greater awareness among the not so active WVGs and women. The UMP not only registered the presence of rural women on the political landscape of the state, but the campaign encouraged many women to participate at the village and block level, evidenced through many women contesting on unreserved seats during the following panchayat elections.

Thus, the process nurtured women leaders but more significantly, women as active citizens, and created deliberative spaces which the panchayats and gram sabhas should ideally aspire to be. Debates on gender reservation tend to focus on women as individuals, highlighting the social and familial aspects only in the context of pointing out impediments to real participation. The UMP's endeavour of harnessing and building the collective strength of women but also of initiating democratic processes within the village community by emphasising principles of inclusiveness (all castes, economic groups to be included in decision-making on everyday issues), achieved through continuous facilitation and sustained effort over several years, illustrates the need for looking at political participation and governance as an exercise in building collective processes for identifying needs and facilitating negotiation, as opposed to equating it simply with leadership and performance. 


\section{Notes}

* The study on Uttarakhand Mahila Parishad was conducted by ISST for Uttarakhand Seva Nidhi Paryavaran Shikshan Sansthan, Almora and supported by Rajeshwar Susheela Dayal Charitable Trust, New Delhi. The authors would like to thank the staff at USNPSS, Almora for their valuable insights and logistical help, particularly Dr Lalit Pande, Anuradha Pande and Renu Juyal; the workers from various CBOs and all the women who participated in the study and generously gave their time and shared experiences with warmth and enthusiasm.

1 Panchayati Raj, the three-tier system of local governance in rural areas constituted in every state in India since 1992, comprises elected councils at village level (panchayats), intermediate and district levels with five-year terms. The gram sabha (village assembly) consists of all persons on the village electoral rolls.

2 For example, The Hunger Project, active in India since 1984, seeks to empower women as

\section{References}

Academics for Panchayati Raj (2009) 'Record of the Proceedings of the National Consultation, held at Vigyan Bhavan Annexe, 25-26 February 2009', http://panchayat.nic.in/data/ 1242973346920 Record\%20of\%20the\%20 proceedings $\% 20$ of $\% 20$ the $\% 20$ National $\% 20$ Conference\%20on\%20Academics\%20for\%20 Panchayati\%20Raj\%20-\%20February\% 202009.pdf (accessed 11 May 2010)

Ban, R. and Rao, V. (2006) Tokenism or Agency? The Impact of Women's Reservations on Panchayats in South India, March, www.cultureandpublicaction.org/ bijupdf/reservations_0313_wtables.pdf (accessed 25 May 2010)

Bisht, Medha and Sudarshan, Ratna (2005) Women in Leadership Positions: A Scoping Paper, New Delhi: Institute of Social Studies Trust

Chattopadhyay, Raghabendra and Duflo, Esther (2003) The Impact of Reservation in the Panchayati Raj: Evidence from a Nationwide Randomized Experiment, November, http://econ-www.mit.edu/ files/769 (accessed 26 May 2010)

Government of India (2010) Economic Survey 2009-10, New Delhi: Government of India key change agents and 'facilitates the leadership of elected women leaders with key interventions in each year of their five year tenures'. See the website: www.thp.org/ where_we_work/south_asia/india/overview (accessed August 2010).

3 Uttarakhand, one of the first states to introduce 50 per cent reservation for women in panchayats, currently has 55 per cent EWRs in the panchayats.

4 While there is substantial research on EWRs, there is insufficient analysis on the working of gram sabhas and women's participation and attendance in them.

5 Prior to January 2007, 'Uttarakhand' was officially known as 'Uttaranchal'.

6 Anganwadis - Childcare centres; focal point for service delivery to children below six years of age, pregnant women, nursing mothers and adolescent girls; a central government sponsored scheme - Integrated Child Development Scheme.

Government of India (2008) Study on Elected Women Representatives in Panchayati Raj Institutions, New Delhi: Ministry of Panchayati Raj, Government of India

Government of India, Ministry of Health and Family Welfare with the International Institute for Population Sciences (2009), National Family Health Survey 3 (NFHS-3), India, 2005-2006, Mumbai: International Institute for Population Sciences; Calverton, Maryland: ICF Macro

Sara, D. and Pande, Anuradha (2008) When a Woman Campaigns, Women Win, International Museum of Women, online exhibition: Women, Power and Politics, www.imow.org/ $\mathrm{wpp} /$ stories/viewstory? storyld $=1827$ (accessed March 2010)

Sharma, Divya (2010) Uttarakhand Mahila Parishad (Uttarakhand Women's Federation), New Delhi: Institute of Social Studies Trust

USNPSS (2008) Annual Report (2008-2009), Almora: Uttarakhand Seva Nidhi Paryavaran Shiksha Sansthan 